\title{
STRATEGI PENYANDIAN METODE STORIES DAN LOKASI UNTUK MENINGKATKAN KEMAMPUAN HAFALAN ANAK
}

\author{
Triana Lestari ${ }^{1}$ \\ trianalestari@upi.edu
}

\begin{abstract}
ABSTRAK
Penelitian ini dilakukan dalam rangka mengembangkan model SMART (Stories Method and Recall Training) melalui teknik asosiasi konyol (Ridiculous Asociation) dalam sebuah cerita. Permasalahan utama dalam penelitian ini adalah apakah metode stories dan lokasi dapat meningkatkan kemampuan hafalan siswa? Partisipan dalam penelitian ini adalah anak sekolah dasar, kelas VI, dengan kisaran usia antara 12-14 tahun, atau berada pada tahap keempat dari perkembangan kognitif, yaitu tahap operasional formal (Hurlock,1978). Metode penelitian yang digunakan adalah eksperimen (one group pre-test-post-test design). Data yang dikumpulkan berupa catatan (record) hafalan anak terhadap sekumpulan gambar yang ditampilkan. Data terdiri dari hasil pengukuran jumlah hafalan dengan metode konvensional dan dengan metode stories lokasi. Data yang terjaring dianalisis dengan t-test (paired sample $t$-test). Hasil penelitian menunjukan bahwa strategi penyandian metode stories dan lokasi dapat meningkatkan kemampuan hafalan siswa. Peningkatan skor ini signifikan, namun tidak menunjukan hubungan yang signifikan antara kemampuan hafalan siswa sebelum diberikan metode stories dan sesudah diberikan metode stories sehingga sumbangan metode terhadap peningkatan kemampuan hafalan siswa hanya sebesar $18 \%$ saja, sedangkan sisanya, $81 \%$ kemungkinan disebabkan faktor memori siswa, dikarenakan objek yang ditampilkan pada saat sebelum dan sesudah perlakuan adalah objek yang sama. Hasil penelitian ini merekomendasikan guru untuk menerapkan metode stories lokasi dengan harapan siswa mampu mengingat materi pelajaran dengan mudah dan tahan lama sehingga dapat meningkatkan prestasi belajarnya.
\end{abstract}

Kata Kunci: Metode Stories \& Lokasi, Kemampuan Menghafal Anak

\section{A. PENDAHULUAN}

Manusia dewasa mempunyai lebih dari 100 milyar neuron, yang satu sama lain berhubungan secara spesifik dan rumit sehingga memungkinkan untuk mengingat, melihat, belajar, berpikir, kesadaran dan lain-lain (Schatz, 1992). Mengingat merupakan salah satu aktivitas mental pada pusat kesadaran atau otak. Informasi yang diterima alat indera akan diberi tafsiran atau makna dan masuk ke dalam penyimpanan sementara (short term memory) yang jika diperkuat dengan aktivitas penyandian, informasi kemudian akan dikirim dan disimpan di memori jangka panjang, untuk digunakan atau diungkapkan kembali pada waktu yang ditentukan.

Salah satu aktivitas mengingat adalah menghafal. Definisi hafal menurut Kamus Besar Bahasa Indonesia adalah; 1. telah masuk dalam ingatan (tentang pelajaran); 2. Dapat mengucapkan di luar kepala (tanpa melihat buku atau catatan lain). Sedangkan menghafal adalah berusaha meresapkan ke dalam pikiran agar selalu ingat.

Aktivitas menghafal selalu muncul sepanjang hidup kita. Kajian tentang hafalan memiliki sejarah yang panjang walaupun "tujuan dari teori yang koheren, terpadu dan memuaskan tentang memori/ hafalan manusia" (Estes, 1976;11) masih belum tercapai, ada kemajuan yang dapat dirasakan dalam strategi-strategi menghafal saat ini. Banyak prinsip

\footnotetext{
${ }^{1}$ Dosen Kampus UPI Cibiru
} 
instruksional dikembangkan yang tujuannya adalah untuk mengajarkan strategi-strategi menghafal dan membantu siswa belajar lebih efektif. Sebagai contoh, pilihan materi yang menjadi focus pengajaran guru akan berpengaruh pada proses penerimaan informasi siswa. Banyak objek disajikan pada individu dalam waktu yang singkat dan hanya objek yang mendapat perhatian yang mampu masuk dalam ingatan dan hanya dengan latihan, siswa dapat mempertahankan objek tersebut lebih lama seraya membangun dasar ingatan yang lebih kuat (Estes, 1976;7).

Mengingat merupakan hal yang mendasar dalam efektivitas intelektual. Menghafal dan mengingat merupakan aktivitas aktif yang cukup menantang. Kapasitas dalam memperoleh informasi, memadukannya secara lebih bermakna dan mendapatkannya kembali dalam tindakan merupakan hasil dari pembelajaran hafalan yang sudah baik. Mengembangkan kemampuan semacam ini dapat meningkatkan kekuatan kita dalam belajar, menghemat waktu dan memperoleh informasi dengan baik. Beberapa dari kita menjadi penghafal yang efektif, tetapi beberapa yang lain tidak.

Menurut Putra dan Issetyadi, salah satu faktor yang mempengaruhi kualitas menghafal, (2010:16) adalah cara memproses stimulus atau informasi. Menurut Prof. Surya dalam bukunya yang berjudul strategi kognitif dalam proses pembelajaran (2015), pemrosesan informasi yaitu proses mengirim informasi dari memori jangka pendek ke memori jangka panjang. Dalam proses ini yang paling penting adalah strategi yang diupayakan agar informasi atau pengetahuan dapat disimpan pada memori jangka panjang sedemikian rupa agar dapat disimpan secara baik sehingga mudah untuk diingat atau diungkapkan kembali manakala dibutuhkan. Salah satu strategi penyandian adalah menghafal (mnemonics).

Pada dasarnya, banyak sekali prinsip-prinsip dan teknik-teknik untuk meningkatkan kapasitas memori kita, seperti kesadaran (awareness), asosiasi (association), system link (link system) dan lain lain.

1. Meski telah banyak "system memory" yang terkenal yang telah dikembangkan, dan beberapa penelitian menggunakan prinsip-prinsip yang sama namun pada penelitian ini, peneliti ingin menguji keefektifan strategi menghafal (mnemonics) melalui metode cerita dan lokasi, untuk meningkatkan kemampuan hafalan individu. Penelitian ini dilakukan dalam rangka mengembangkan model SMART (Stories Method and Recall Training) melalui teknik asosiasi konyol (Ridiculous Asociation) dalam sebuah cerita. Meskipun asosiasi merupakan dasar memori, kekuatannya sebenarnya dapat diperbesar seandainya hal yang diasosiasikan diwujudkan sebagai hal yang lucu, sesuatu yang tidak mungkin, atau tidak masuk akal. Sehingga anak dengan mudah mengingatnya kembali. Berdasarkan penjelasan diatas, maka masalah penelitian yang akan dikaji dalam penelitian ini adalah: 1) Bagaimana kemampuan awal hafalan siswa?, 2) Bagaimana kemampuan hafalan siswa setelah diajarkan metode stories dan lokasi?, 3) Apakah metode stories dan lokasi dapat meningkatkan kemampuan hafalan siswa? Penelitian ini mengusung tema encoding atau penyandian sebagai bagian dari sistem pemrosesan informasi. Terdapat berbagai strategi penyandian yang berdampak langsung pada proses penyimpanan dan pengungkapan kembali informasi. Sehingga proses kognisi berjalan lebih efektif dan efisien

\section{Makna Penyandian}

Encoding atau penyandian merupakan salah satu langkah dalam keseluruhan informasi yaitu proses mengirim persepsi dari memori jangka pendek ke memori jangka panjang. Dalam proses ini yang paling penting adalah strategi yang diupayakan agar informasi atau pengetahuan dapat disimpan pada memori jangka panjang sedemikian rupa agar dapat disimpan secara baik sehingga memudahkan untuk diingat dan diungkapkan kembali manakala dibutuhkan. Untuk itu, semua informasi harus dikemas dalam bentuk encode atau sandi-sandi tertentu sehingga memudahkan untuk menyimpan dan mengungkapkannya kembali pada saatnya. Dalam bahasan ini encoding dipadankan dengan penyandian atau proses membuat sandi. 
Proses penyandian ini dapat diumpamakan ketika kita harus menyimpan barang-barang di dalam rumah. Semua barang harus dipilah-pilah serta dikemas agar dapat disimpan dengan baik pada tempatnya masing-masing, dan memudahkan untuk mengambilnya kembali pada saat diperlukan. Misalnya, pakaian disimpan di dalam lemari pakaian, buku-buku atau alat tulis disimpan dikamar kerja, bahan makanan disimpan di dapur atau di tempat penyimpanan makanan. Makanan pun harus dipilah-pilah menurut jenisnya dan keperluannya, misalnya daging disimpan dalam kulkas, beras didimpan dalam tempat beras, ikan dalam kulkas, dsb. Dengan mengatur penyimpanan yang dikemas secara baik dan pada tempatnya, maka akan mempermudah mencari dan mengeluarkannya pada saat diperlukan. Perumpamaan lainnya adalah pada saat kita menyimpan informasi data ke dalam komputer. Kita mengatur data masukan ke dalam blok data yang berupa folder atau file secara sistematis dan teratur, agar dapat diunduh dengan mudah.

Demikian pula proses penyandian atau penyimpanan informasi dalam proses kognitif. Apabila informasi atau pengetahuan disandikan dengan baik, maka kita akan dengan mudah mengenalnya dan mengeluarkannya pada saat diperlukan.

\section{Penyandian Informasi Sederhana}

Ada dua macam proses penyandian yaitu penyandian informasi sederhana dan informasi yang lebih bersifat kompleks. Untuk informasi sederhana ada sejumlah strategi penyandian, yaitu; rehearsal (latihan), mediation (mediasi atau penyela), imagery (bayangan atau gambaran), dan mnemonic (menghafal). Pada penelitian ini, peneliti menggunakan strategi mnemonic yang merupakan strategi penyandian dengan menghafal informasi dengan cara mengkreasikan sandi-sandi informasi baru ke dalam sandi-sandi yang lebih terurai sehingga membantu dalam proses penyimpanan dan pengungkapannya. Secara khas, mnemonic melibatkan pemasangan informasi yang harus diingat dengan informasi yang telah dipelajari dengan baik agar informasi baru dapat lebih mudah diingat. Strategi ini memudahkan kita mempelajari informasi baru dan membuatnya lebih mudah untuk diurai, dikelompokkan dan diungkapkan dari memori. Strategi ini dapat dilengkapi dengan menggunakan beberapa perilaku seperti sajak (puisi), ucapan, atau isyarat badan dalam prosesnya. Strategi mnemonic dapat dilaksanakan dengan beberapa metode, salah satunya adalah dengan metode stories dan lokasi.

\section{Strategi Penyandian Metode Stories dan Lokasi}

Metode Stories adalah cara mengingat dengan membuat cerita. Dalam metode ini butir-butir yang harus diingat dirangkaikan sedemikian rupa sehingga menjadi suatu cerita. Misalnya, seorang anak harus mengingat beberapa benda yang akan dibawa besok ke sekolah, yaitu pensil, kalkulator, buku tulis, penghapus, roti untuk bekal, air minum, penggaris, dan atlas. Untuk memudahkan mengingatnya, siswa membuat sebuah cerita sebagai berikut:

"Seorang raja sedang memperhatikan peta suatu kota dalam atlas dan menuliskannya dengan pensil di buku tulis. Tiba-tiba ia meminta roti dan air minum yang tersimpan dekat kalkulator dan penggaris".

Sedangkan metode lokasi atau metode loci adalah metode dengan membayangkan lokasi tertentu terhadap informasi yang harus diingat/ dipelajari. Dalam menggunakan metode loci untuk mempelajari informasi baru, harus membayangkan terlebih dahulu suatu lokasi, seperti ruangan sekolah, rumah, jalan dsb. Lokasi itu kemudian dilatihkan sehingga orang dengan mudah membayangkan menaruh sesuatu di lokasi itu, misalnya kursi, meja, sofa, tempat tidur disimpan di rumah. Sesuatu yang ditaruh harus dipeajari dengan baik sehingga dapat diungkapkan secara tepat dengan urutan yang sama di setiap waktu. Begitu lokasi dan sesuatu yang ditaruh telah berkali-kali dipelajari, maka system siap untuk digunakan sebagai hafalan. 


\section{METODE}

Penelitian ini menggunakan metode eksperimen (one group pre-test-post-test design). Dasar pemilihan desain disesuaikan dengan tujuan penelitian, dimana peneliti akan mengukur dampak penerapan metode stories dan lokasi terhadap kemampuan hafalan siswa, sehingga untuk mengukur dampak penerapan tersebut, diperlukan pengukuran awal dan akhir sebagai pembanding skor.

Data yang dikumpulkan berupa catatan (record) hafalan anak terhadap sekumpulan gambar yang ditampilkan. Data terdiri dari hasil pengukuran jumlah hafalan dengan metode konvensional dan dengan metode stories lokasi. Selain itu, peneliti juga melengkapi data, yang merupakan testimoni siswa terhadap metode yang digunakan.

Partisipan dalam penelitian ini adalah anak sekolah dasar, kelas VI, dengan kisaran usia antara 12-14 tahun, atau berada pada tahap keempat dari perkembangan kognitif, yaitu tahap operasional formal (Hurlock,1978). Pada tahap ini, anak telah mampu menalar serta menggabungkan informasi dari sejumlah sumber. Sehingga jika dikaitkan dengan penguasaan tugas perkembangan kognitif tersebut, anak akan mampu mengingat sejumlah informasi dan menggabungkan informasi tersebut dalam sebuah cerita. Hal ini diyakini dapat memudahkan anak dalam menyimpan informasi dan mengungkapkannya kembali, jika sewaktu-waktu informasi tersebut diperlukan.

Alat pengumpul data dalam penelitian ini berupa sekumpulan gambar benda, buah, binatang dsb, sejumlah 60 buah yang harus diingat dan diungkapkan kembali melalui tulisan dalam jangka waktu 90 detik. 30 buah gambar ditampilkan pada pengukuran awal, 30 buah sisanya ditampilkan pada pengukuran berikutnya (post test).

Data diolah dengan SPSS dan dianalisis dengan t-test (paired sample t-test). Uji ini melibatkan pengukuran pada subjek yang sama terhadap suatu perlakuan tertentu. Apabila suatu perlakuan tidak memberi pengaruh, maka perbedaan rata-rata adalah nol. Dalam penelitian ini, t-test digunakan untuk membandingkan kemampuan hafalan siswa sebelum dan setelah diajarkan metode stories dan lokasi).

\section{HASIL DAN PEMBAHASAN}

Matlin (2014), dalam bukunya cognitive psychology menyatakan bahwa anak d usia 11-12 tahun, memiliki memori kerja yang lebih mengesankan dibanding anak berusia 9 tahun yang dianggap mampu merecall 6 dalam satu deret kata/angka (Cowan dkk., 2009). Namun faktanya ada beberapa anak yang pencapaiannya masih dibawah kondisi ideal.

Hasil pengolahan data menunjukan bahwa kemampuan hafalan siswa mengalami peningkatan dari 15,52 menjadi 18,67. Dengan t hitung -2, $569<\mathrm{t}$ tabel 2.08596 maka. peningkatan skor sebelum dan sesudah perlakuan signifikan ( $\mathrm{H}_{0}$ ditolak). Namun Sig.0.054 > 0.05. Hal ini menunjukan tidak ada hubungan yang signifikan antara kemampuan hafalan siswa sebelum diberikan metode stories dan sesudah diberikan metode stories.

Sumbangan metode terhadap peningkatan kemampuan hafalan siswa adalah $0.426^{2}=$ $0.181476(18,1476 \%)$ sisanya, $81.8524 \%$ disebabkan faktor lain. Faktor yang paling berpengaruh adalah memori siswa, hal ini dikarenakan objek yang ditampilkan pada saat sebelum dan sesudah perlakuan adalah objek yang sama, sehingga, siswa sangat dimungkinkan mengingat banyak objek yang ditampilkan sebelum perlakuan diberikan. Namun demikian, mayoritas siswa menunjukan sikap senang dengan metode ini, yang dinyatakan dalam testimony siswa terhadap metode ini. Seperti statement bahwa metode ini menyenangkan, mudah dihafal, mudah diingat, dan lain lain.

\section{E. KESIMPULAN}

Berdasarkan hasil penelitian, dapat disimpulkan bahwa strategi penyandian metode stories dan lokasi dapat meningkatkan kemampuan hafalan siswa. Peningkatan skor ini signifikan, 
namun tidak menunjukan hubungan yang signifikan antara kemampuan hafalan siswa sebelum diberikan metode stories dan sesudah diberikan metode stories. Hal ini disebabkan adanya variable lain yang dimungkinkan mempengaruhi hasil. Sehingga sumbangan metode terhadap peningkatan kemampuan hafalan siswa hanya sebesar 18,1476 \% saja, sedangkan sisanya, $81.8524 \%$ kemungkinan disebabkan faktor memori siswa, dikarenakan objek yang ditampilkan pada saat sebelum dan sesudah perlakuan adalah objek yang sama. Hasil penelitian ini dapat dijadikan acuan untuk penelitian berikutnya dengan memperluas cakupan serta antisipasi kesesatan, yang dimungkinkan dapat memengaruhi hasil eksperimen.

\section{DAFTAR PUSTAKA}

Creswell, John W. (2010). Research Design Pendekatan Kualitatif, Kuantitatif, dan Mixed.Yogyakarta : Pustaka Pelajar

Elizabeth B. Hurlock. (1978). Perkembangan Anak. Jakarta: Erlangga

Matlin, Margaret W. (2014). Cognitive Psychology Eighth Edition International Student Version. Printed In Asia: John Wiley \& Sons, Inc.

Surya, Mohamad. (2015). Strategi Kognitif dalam Proses Pembelajaran. Bandung: Alfabeta 